\title{
Vallási szocializáció vizsgálata fiatal felnőttekkel készített interjúk tükrében ${ }^{1}$
}

\author{
Pusztai Gabriella - Demeter-Karászi Zsuzsanna \\ https://doi.org/10.51624/SzocSzemle.2019.3.4 \\ Beérkezés: 2019. 02. 19. \\ Átdolgozott változat beérkezése: 2019. 07. 01. \\ Elfogadás: 2019. 10. 11.
}

\begin{abstract}
Összefoglaló: A nagymintás vallásszociológiai vizsgálatok adatainak értelmezési nehézségei miatt sürgető feladattá vált a vallási szocializáció fogalmának alaposabb vizsgálata. A szocializációs elméletek finomodása nyomán felvetődik a kérdés, vajon a szocializáció reprodukciós vagy konstruktivista felfogására építve értelmezhető-e a vallási transzmisszió. Jelen tanulmányban 18 kvalitatív interjút elemeztünk, melyeket a fiatal felnőtt korosztályban vettünk fel. Arra a kérdésre kerestük a választ, hogy a vallási szocializáció korábbi elméletei alkalmazhatók-e a fiatal generáció jellemzésének megalkotásához és vallási változások értelmezéséhez, vagy pedig az aktív, alkotó, már az életút elején is újrakonstruálódó vallásosság írja le jobban a tapasztalt jelenségeket. Mivel a vallásosság többdimenziós jelenség, s külön kívántuk vizsgálni az egyes dimenziókban történő fejlődést, Glock és Stark modelljét vettük alapul az interjúk elemzése és nyitott kódolása során. Az elemzés eredményeképpen a vallási szocializáció hét típusát tudtuk elkülöníteni. Eredményeink a vallási szocializáció konstruktivista értelmezését erősítik.
\end{abstract}

Kulcsszavak: vallási szocializáció, a vallásosság intergenerációs átörökítése, a vallásosság dimenziói, konstruktivista szocializációértelmezés

\section{Bevezetés}

A kutatásokban gyakran maradnak megválaszolatlanul a vallásosságról feltett kérdések, s nemcsak azért, mert a legbelsőbb magánszférát érintik, hanem azért is, mert nagyon összetett jelenségről van szó, melyet leegyszerüsítve próbálnak kitapintani a kutatók (Tomka 1998; Földvári 2014). A változó vallási trendek mellett fontos és aktuális kutatói feladat a vallásosságot mérő régi, bevált kérdések folyamatos felülvizsgálata, amit a jelenség aprólékos vizsgálatának kell megelőznie. Időről időre megállapítást nyer, hogy a vallásosság s fóként a vallási szocializáció folyamatainak tanulmányozására a kvantitatív kutatások nem kínálnak elég részletgazdag információt, nem tárják fel a vallásosságnak az életút során történő formálódását, nem mutatnak rá a vallásosság leírására használt fogalmak finom, egyéni szintủ distink-

1 A cikk a Nemzeti Kutatási, Fejlesztési és Innovációs Hivatal NKFI Alapjából támogatott K 119679 nyilvántartási számú „Vallási változás Magyarországon" című kutatási projekt támogatásával valósult meg. 
cióira, amire a kvalitatív kutatások képesek lehetnek (Myers 1996; Gereben 1997; Gereben 2003; Bögre 2017).

A nagy volumenú átfogó kutatások csupán egy-egy rövid kérdésblokk erejéig vizsgálják a vallásosságot, s ezek alapján gyakran felszínes vagy ellentmondásos kép bontakozik ki a vallásosságról, a vallási szocializációra vonatkozó kérdés pedig ritkán szerepel a kutatásokban. Például a Magyar Ifjúság kutatássorozat tartalmaz vallásos neveltetésre vonatkozó kérdést. Eszerint a vallásos nevelésben részesült fiatalok aránya fokozatosan csökken, 2008-ban a fiatalok egyharmada, 2012-ben valamivel több mint egynegyede, 2016-ban pedig kevesebb mint egynegyede állította magáról, hogy vallásos szellemben nevelték (Pusztai 2014, 2019). Ugyanezen adatokat közelebbről megvizsgálva azonban feltűnik, hogy miközben a vallásos nevelésben részesülő fiatalok 85-90\%-a vallásosnak tartja magát - igaz, nagyjából a negyedükből lesz az egyházak tanítását követő személy -, a vallásos nevelésben nem részesülők egy része - 2008-ban és 2016-ban egyharmaduk, 2012-ben egyötödük - viszont szintén vallásosként sorolja be önmagát. Nem tudhatjuk természetesen, hogy a kérdésre válaszolva a fiatalok hogyan értelmezték a vallásos neveltetés fogalmát. Ha a családon belüli, a szülők részéről történő szándékos vallási transzmisszióra gondoltak, akkor úgy tủnik, hogy a vallási szocializáció más ágensei is bizonyulhatnak hatékonyabbnak a családénál. Az adatok értelmezésekor az is óvatosságra int, hogy a fenti kutatás során vizsgált korcsoport tagjai között akár másfél évtizednyi korkülönbség is lehet, s a szakirodalomban gazdagon adatolt tény, hogy az adoleszcens, posztadoleszcens évek komoly fordulatot hozhatnak a vallásosság terén, sőt a vallásos identitás igen képlékeny, változékony lehet ebben a periódusban (Lee et al. 2019; Kovács 2014; Bögre 2017). Mindent egybevetve valójában nem tudjuk, hogyan megy végbe ma a fiatalok vallási szocializációja, s milyen tényezők befolyásolják a vallási transzmisszió eredményét.

Jelen kutatásban 18 kvalitatív interjút elemeztünk, melyeket a fiatal felnőtt korosztályban vettünk fel. Arra a kérdésre kerestük a választ, hogy a vallási szocializáció korábbi elméletei alkalmazhatók-e a fiatal generáció jellemzésére és vallási változások értelmezéséhez, vagy pedig az aktív, alkotó, már az életút elején is újrakonstruálódó vallásosság koncepciója írja le jobban a tapasztalt jelenségeket. Mivel a vallásosság többdimenziós jelenség, külön kívántuk vizsgálni az egyes dimenziókban történő változást, Glock és Stark (Glock 1962) modelljét is felhasználtuk az elemzés során, melynek eredményeképpen hét típust tudtunk elkülöníteni az interjúalanyok vallási szocializációja alapján.

\section{A vallási transzmisszió}

A vallásos kultúra átadását tanulmányozva egyértelmű, hogy eltérő módon és hatással örökíthetők át a vallási ismeretek, a hittételek, a tapasztalatok, a gyakorlatok és a vallási alapon álló mindennapi magatartásminták, de kétségtelen, hogy mindez 
olyan interakciós folyamatok során történik, melyek keretén belül különböző szocializációs ágensek rendkívül sokféle módon befolyásolhatják az egyének vallásos meggyőződésének alakulását (Sherkat 2003). Nemzetközi és hazai kutatások eredményei megegyeznek abban a tekintetben, hogy a családi környezet szerepe meghatározó az egyének vallási szocializációjának alakulásában (Hart 1990; Pusztai 2004).

A családi vallásosság befolyását, a vallásosság eredményes vagy kevésbé eredményes átörökítését ugyanakkor ellentmondásokkal telinek ítéli meg a szakirodalom, és a család számos jellemzője tovább színezi a hatásmechanizmus érvényesülését (Hayes-Pittelkow 1993). Vita folyik arról, hogy az anya szerepe vagy az apa hatása erősebb, sőt egyesek arra a következtetésre jutnak, hogy a szülők szerepe más-más dimenzióban válik jelentőssé (Hoge-Petrillo 1979; Hayes-Pittelkow 1993). Korábbi kutatásaink során azt tapasztaltuk, hogy mivel az anyák nagyobb arányban vallásosak, a vallásosság eredményes átörökítése nem az anyai vallásosságtól függ: a felsőoktatási hallgatók körében az apa vallásossága mutatkozott differenciáló tényezőnek (Pusztai 2011). A szülók értékrendi, vallási-világnézeti, sőt felekezeti homogámiája, azonos vallásgyakorlati intenzitása jelentős, önálló hatótényezőként azonosítható a gyermeknevelés számos területén (Pusztai 2016). A vallási szocializáció sikere részben, de nem kizárólagosan, azon múlik, hogy a szülők vallása, vallásossága, hitrendszere mennyire egységes. A szülők közötti egyetértés szignifikánsan eredményesebb vallási transzmissziót tesz lehetővé, ellenkező esetben az utódok vallási elköteleződése gyengébbnek mutatkozik, vallási heterogámia esetén pedig az apa hatása erősebbnek tûnik (Hoge-Petrillo 1978).

A család mellett további igen fontos ágenseket határoz meg a szakirodalom a vallási szocializáció kapcsán. Az egyik ilyen a vallásgyakorló közösség, a másik pedig a kortárs kapcsolatháló (Martin et al. 2003). Többnyire egyetértés mutatkozik ezen ágensek fontosságának megítélésében: a kortárs kapcsolatháló összetétele különösen a tizenévesek számára válik döntő fontosságúvá a vallási nézetek formálódása tekintetében is (Pusztai 2004). Igaz, a kutatások egy része szerint a kortárs vagy intézményi hatás valójában a szülői vallásosság hatásának közvetítője, hiszen a vallásos szülők ennek megfelelő közösségekbe és intézményekbe „csatornázzák” a gyermeküket (Desrosiers et al. 2011; Todd et al. 2003). Kutatásaink során magunk is rámutattunk a barátok, iskolatársak, hallgatótársak vallási szocializációt jelentősen befolyásoló szerepére (Pusztai-Verdes 2002; Pusztai 2012). Az Európába érkezett muszlim fiatalok vallási szocializációját elemző tanulmányok szerint a baráti és lakóhelyi, valamint a kisebbségi közösségek, szervezetek vallási szocializációs potenciálja a várakozásnál jelentősebb (Maliepaardet al. 2012; Lagrange 2014).

Az életkori változásokat, a serdülő- és ifuúkor meghatározó szerepét a klasszikus vallási szocializációs elméletek is hangsúlyozták (Pusztai 1997). Fowler hat plusz egy szakaszt különböztetett meg a hit fejlődésében: véleménye szerint a hit univerzális és folyamatos fejlődésben van az életút során (Fowler 1982). Erikson elméletét 
továbbgondolva a vallásosság egész életen át tartó fejlődését hangsúlyozza, kiemelve a krízisek, a kételkedés és a kritika szerepét, melyek hozzájárulnak a reflektív hit kialakulásához. Konszenzus mutatkozik abban a tekintetben, hogy az egyik legjelentősebb életkori szakasznak a fiatal felnőttkort tartják (Ozorak 1989). A kibővülő szocializációs színtereken az iskolarendszer, a felsőoktatás vagy a munkahely közegében újraértelmezik a vallásossághoz való korábbi viszonyukat. Nincs vita arról, hogy ez a vallásosság kritikájának, újragondolásának fontos időszaka, azonban az egyes fejlődési stációk megélésének társadalmi sokszínűségére, lehetséges változataira, a változások irányaira kevés kutatás koncentrál. A gyermekkor és a felnőttkor közötti átmenet vallásos dimenziója tekintetében azonosítható fejlődési útvonalakat vizsgálva a korábbi beállítódás mellett stabilan kitartók és a változtatók között tehetünk különbséget attól is függően, hogy honnan indultak, de a vallásosság többdimenziós szemlélete, a különböző dimenziókban mérhető eltérő intenzitás tovább gazdagítja a képet (Petts 2009; Lee et al. 2019).

A szocializációs elméletek finomodásával együtt a vallási szocializáció egyirányú és lineáris, rekonstrukciós modelljei is megértek a felülvizsgálatra (Pusztai 1997; Somlai 1999). A strukturalista-funkcionalista értelmezés szellemében a szocializáció a kész családi magatartásminták és vallásgyakorlati modellek követését jelentette, az előírt intézményi keretek közé való beilleszkedést, az egyirányú, lineáris hatásgyakorlást. Ebben az értelemben a vallási szocializáció is időszakos jellegű lenne, egy életkori szakaszra koncentrálódna. A végeredmény pedig vagy az, hogy az új generáció betagozódik a hagyományos, szülők által reprezentált vallásgyakorlati rendbe, vagy az, hogy a szülei vallástalanságát viszi tovább.

Napjainkra a szocializáció konstruktivista és kapcsolathálózati modelljei jelentősen átalakították a vallási szocializációról alkotott felfogásunkat is (Martí 2015; Hunt 2015). A lineáris, teleologikus és passzív modell helyét az aktivitást, kölcsönösséget és a folyamatjelleget hangsúlyozó modell foglalta el (Sherkat 2003; Pusztai 2019). A csoportban való szociális tanulás jellegzetességeit mutató vallási szocializációt a vallási, spirituális tartalmak és élmények értelmezésének és a vallásgyakorlatnak az egyéni, illetve társas konstrukciója jellemzi. A korábbi modellben a vallási szocializáció mintázatai, valamint a demográfiai jellemzők és a társadalmi státustényezők közötti alapvetô és szignifikáns összefüggéseket írták le meghatározóként, a konstruktivista vallási szocializációs modellben viszont hangsúlyt kapnak az egyént körülvevő közösségek, az életcélok és az életstílus környezeti változatossága, az életúton belüli töredezettség, a változások folyamatjellege.

Az egyének vallási szocializációjának értelmezését meghatározó rekonstrukciós modell szerint kiemelkedő ágensek a szülők, az egyházak és az iskola, melyek kész mintákat adnak át. Az egyének pedig egyszerűen magukévá teszik a másoktól tanult és látott magatartásformákat, és elsősorban az idősebb generációt követve passzívan befogadnak egy végérvényesen lezárt „tananyagot”. A konstruktivista szocializációs értelmezés szerint elsősorban a vallási kínálat sokfélesége, illetve az ezt 
kísérő bizonytalanság állandó újragondolásra kényszeríti az egyént, aki így a saját vallásosságával kapcsolatos választásait is folyamatos kritikával szemlélve újraalkotja, finomítja vallásosságát (Martí 2015; Hunt 2015). A konstruktivista modell az egyén alkotó szerepét hangsúlyozza, aki kritikus, folyamatosan válogat és innovál. A modell kiemelkedő szocializációs ágenseit az egyének maguk választják, s új értelmező közösségeik tagjaiként, megújuló perspektívába állíthatják a korábban kiépült vallásosságukat. Egy konstruktivista megközelítés szerint az egyén a pillanatnyi szituációban mindig újra- és újraalkotja a vallási identitását, míg mások szerint a vallási identitás közösségi konstrukciója és az egyén közösségi tagsága valamivel nagyobb stabilitást idéz elő.

\section{A többdimenziós elemzés kiindulópontjai}

A vallásosság többdimenziós megközelítései szerint a vallásos elköteleződés nem határozható meg csupán különböző gyakorisági mutatókkal, mint például a templomba járás, imádkozás rendszeressége (Földvári-Rosta 1998). Glock és Stark ötdimenziós vallásmodellje több évtizede a legmegbízhatóbban strukturálja a rendkívül összetett jelenséget (Glock 1962). Az ideológiai dimenzió, a rituális dimenzió, az élmény- és tapasztalati dimenzió, az intellektuális dimenzió, valamint a hétköznapokban tetten érhető következmények dimenziójának az elkülönítése az elemzések érvényességét erősítette, s vallás- és felekezetközi összevetésre is alkalmas (Földvári-Rosta 1998; Pusztai 2004). Az ideológiai dimenzióba a hit, a személyes meggyőződéssé vált vallási képzetek tartoznak, a rituális dimenzióba a vallásgyakorlat, az egyén vallási mezőben mutatott aktivitása sorolható, amin többnyire a szervezeti részvételt értik. A harmadik dimenzióhoz kapcsolódnak azon élmények és tapasztalatok, melyeket az egyének a vallásosságukkal hoznak kapcsolatba. Az intellektuális dimenzió a vallásos ismereteket méri, végül pedig a következménydimenzió az előző négy dimenziónak a hétköznapi magatartásmintákra gyakorolt hatásait vizsgálja az egyén életében. Ezt a dimenziót két további alegységre bonthatjuk. Az egyik az, hogy az egyén maga mit vár el a vallástól, a másik pedig az, hogy magának az egyénnek a teljesítményében hogyan jelenik meg a vallásosság. Összességében a modell jól alkalmazható a vallásosság komplex voltának szemléltetésére és az adatok rendszerezésére (Tomka 1998; Földvári-Rosta 1998).

\section{A kutatásról}

Kutatásunk adatbázisát 48 mélyinterjú szövegkorpusza adja, melyeket egy kutatócsoport tagjai készítettek egy saját fejlesztésű félig strukturált interjúvázlatra támaszkodva a „Vallási változás Magyarországon” című kutatás részeként. Az interjúk családok három generációját vizsgálták az inter- és intragenerációs vallási változások nyomon követése céljából. Az interjúkat egy előre elkészített interjúvázlat kér- 
dései alapján vettük fel, ám a kérdések megválaszolásakor a válaszadók döntöttek arról, hogy milyen mélységben fejtik ki a válaszaikat. A kutatás egyik legfontosabb módszertani tapasztalata az volt, hogy a téma érdeklődést váltott ki, s a megkérdezettek vallási orientációtól függetlenül döntően alaposan és részletesen válaszoltak. Az interjúvázlat alapvetően életkori szakaszok szerint haladva tette lehetôvé a vallásos életút alakulásának megismerését, öt fő témakör köré szervezve. Az első kérdésblokk a család és a gyermekkori vallásosság kérdéseire fókuszált, a szülői és gyermekkori vallásgyakorlatra. A második kérdéskör a vallásnak az iskoláskor különböző szakaszaiban (az általános és középiskolás korban) bekövetkező változásait taglalta, a vallási ismeretek, gyakorlatok alakulását, az ezzel összefüggő témák megjelenését az osztálytársakkal, pedagógusokkal történő kommunikációban. A harmadik blokk a vallásosság fiatal felnőttkori megélését járta körül, a negyedik a személyes vallásosság kérdéseit ölelte fel, és végül, de nem utolsósorban az ötödik a vallásosság és a jövőre vonatkozó tervek kapcsolatát boncolgatta. Jelen tanulmányban a legfiatalabb korosztályból származó 18 interjú elemzésének tapasztalatait dolgoztuk fel. Amikor a fiatal generáció vallásosságát vizsgáltuk az interjúkban, el kívántuk különíteni a vallásosság különböző dimenzióiba sorolható jelenségeket, mert azt tapasztaltuk, hogy a változás és a stabilitás párhuzamosan jelen lehet a különböző dimenziókban. Az elemzés eredményének tekintjük, hogy a rendkívül összetett folyamatokat megfigyelve típusokat tudtunk alkotni és ezekbe soroltuk be interjúalanyainkat.

Az elemzést végső soron annak a kutatási kérdésnek a megválaszolásához való hozzájárulásként végeztük, hogy az elvallástalanodás néven összefoglalt jelenség mögött állhat-e a vallási szocializáció egy új formája, melynek hatására az egyén kritikusabb, önállóbb és alkotó módon fogalmazza meg a vallásossághoz való viszonyát. Az elemzés során Glock és Stark dimenzióit külön-külön vizsgáltuk abból a szempontból, hogy melyek lesznek azon dimenziók, melyekre az inter- és intragenerációs stabilitás, és melyek azok, amelyekre az innováció jellemző.

\section{Eredmények}

A kutatás során megvizsgáltuk a szakirodalomban tárgyaltakat, s összevetettük a magunk alkotta típusokkal, így nyilvánvalóvá vált, hogy a fiatal generáció vallásossága túllép az utánzás, ismétlés keretein, sokkal inkább egy aktív, innovatív, újrakonstruálódó vallásossággal van dolgunk, mely egyénenként többé-kevésbé eltérő változatokat mutat. Megállapítottuk, hogy az előző generáció vallásossága vagy vallásosságtól való távolságtartása, illetve a nézetek szándékos átörökítésre vonatkozó törekvései nem minden esetben bizonyulnak hatásosnak. Az interjúk elemzése során az volt a célunk, hogy kitapintsuk, milyen arányban realizálódik az egyes vallási szocializációs szcenáriókban az eredményes és az eredménytelen transzmisszió, milyen mértékben jellemzi a válaszadók vallási szocializációs történeteit a változás és a 
stabilitás, valamint mennyire jelenik meg a tudatosság és a reflektivitás a történtek felidézése és a válaszadók jelen nézeteinek kifejtése során. A típusalkotás két fő tengelye tehát a változás - stabilitás valamint tudatosság - reflektálatlanság volt. A következőkben egyenként is bemutatjuk a típusokat, minden típusnál külön vizsgálva a család vallásosságát, a fiatal felnőttek vallásos önjellemzését, valamint a vallási ismeretekhez, a hittételekhez való viszonyulást, a tapasztalatok, élmények területét, a vallásgyakorlat karakterét és a vallási alapon álló mindennapi magatartásmintákról szóló önjelentéseket. Az ezekre vonatkozó szövegrészeket - dimenziónként haladva és egymástól függetlenül - nyitott kódolással értékeltük, majd megállapításaikat összevetettük. A típusoknak a kvalitatív kutatási szemlélet alapelveit követve nem az elméletek, a szakirodalom alapján kerestünk nevet, hanem induktív logika szerint a tapasztalati tények és az egyéni interpretációk legkarakteresebb vonásaira utalva. Összesen hét típust határoztunk meg, melyek közül több stabilitás jellemzi a komfortosítva megőrző, az autonóm vallásosságot építő, a nosztalgikus-reflektálatlan, az érdektelen és a tudatosan vallástalan típust, s a változás jelentősebb a valláskárosult és a közeledő típusban. A tudatosság és reflektáltság a legerősebben az autonóm vallásos és a tudatosan vallástalan típusban jelenik meg. Természetesen a szövegek értékelése során, még akkor is, ha összevetettük egymással értelmezésünket, nagyfokú szubjektivitás érvényesült, azonban a szövegek páratlanul gazdag adatanyagában több kapaszkodó segítette az elemzést, mint a kvantitatív kutatások során ez lehetséges lenne.

\section{A komfortosítva megőrző típus}

A komfortosítva megőrző típusba tartozók aktív vallásos környezetben nevelkedtek. „Anyukám és nagymamám tanítottak imádkozni, kicsi korom óta jártunk templomba, szinte minden vasárnap" (lány). Lényeges mozzanat, hogy mivel családjuk erôteljesen beágyazódott a lokális vallási kapcsolathálózatba, ebben ők is otthonosan mozogtak, s a szabadidős tevékenységeiket, kortárs kapcsolataikat is meghatározta ez az odatartozás: „Nagyon szívesen vettem részt ezeken [táborok, hittanórák stb.]. Jó volt a közösség és jó feladatok, hangulat is volt. Egyszóval jó volt minden, játékosan tanultunk. Igaz, én katolikus vagyok, aztán a reformátusok is rendeztek ilyen táborokat, és ott is szívesen láttak minket" (lány). A gyermekkor és a felnőttkor határán állva reflektáltan nyilatkoznak az örökül kapott vallásosságukról: elfogadják az idősebb generáció (szülők, nagyszülők) vallásosságát, ám jól megfigyelhető, ahogyan azt máris árnyalják, testre szabják.

Ami a kognitív dimenziót illeti, a családi és az intézményes vallásos neveltetés eredményeképpen alapos ismeretek, elméleti felkészültség jellemzi az ehhez a típushoz tartozók vallásosságát. Világnézetileg alapvetően azonosulni tudnak az előző generáció nézeteivel, de hangsúlyozzák, hogy a dogmák szó szerinti értelmezése, a kötöttségekhez való ragaszkodás és a fegyelem tekintetében nem tudják követni a szülőket. Mivel készen kapott vallási ismereteket, szokásrendet és normákat visz- 
nek tovább, beleszületés-belenövekedés jellemző rájuk, a megtérésélmény ritka a körükben. Egy-egy érzelemmel áthatott mozzanatot említenek, melyeket vallási élményként azonosítanak, ám ezek nem megváltoztatták, hanem megerősítették őket az öröklött hitrendszerben. Összességében egyértelmúen pozitív élménykontextus jellemzi tapasztalataikat. „Mondjuk, ha elmegyünk templomba, akkor jobban érzi magát az ember" (lány).

Miközben ideológiai stabilitásról számolnak be, mindössze két dimenzióban jelenik meg kisebb változtatás igénye. Egyrészt - úgy véljük, ez a lényegesebb - a vallásossághoz kötődő normák szigorán lazítanának: „...azok olyanok, miket, úgy gondolom, hogy nem egészen haladnak a korral, úgymond. Például az, hogy nem lehet válni egy katolikus egyházban, szerintem ez egy kissé, úgymond maradi, vagy házasság elött együtt élni valakivel, ez sem a legrosszabb dolog a világon, föleg hogyha már nem lehet elválni, akkor olyannal házasodjak össze, akivel együtt tudok élni" (lány). Az újraértelmezés, az innováció nem a hagyományokkal való szakítást jelenti, hanem a személyesen alkalmasabbá, kényelmesebbé, korszerübbé tételt, ami főleg a vallásosság megélését hatja át: „Kicsit más... Természetesen nagyon sok dolog van, amire elismerően tekintek vissza, úgy gondolom, hogy nagyon fontos volt. És igen. De természetesen nagyon sok dolgot változtatnék ezen a vallás megélésen. És az szerintem természetes valamilyen mértékben" (fiú).

A másik dimenzió, melyben a szülők felnőttkori vallásosságához viszonyítva eltérő igényeik vannak, az a rituális dimenzió. „Nem vagyok ott minden szentmisén, csak amikor tudok, de így is jól érzem magam" (lány). Hangsúlyozzuk azonban, hogy a szülői életutakat is tartalmazó szöveges anyag azt mutatja, hogy a megkérdezés pillanatában erős rituális elkötelezettséggel és aktivitással rendelkező felnőttek is beszámoltak vallásos életútjuk eltérően aktív periódusairól, ezért talán fontosabb karaktervonásnak tartjuk a normarendszerrel kapcsolatos finom elmozdulást. Ezt a típust tehát az ideológiai és az intellektuális dimenzió megtartása jellemzi, az élmények dimenziójában a stabilitás dominál, a rituális dimenzióban komfortosít, a konzekvenciális dimenzió bizonyos területein lazít az öröklött mintázatokon.

\section{Autonóm vallásosságot épitő típus}

Nem állnak igazán távol az előbbi típustól az autonóm vallásosságot építő típusba tartozók, mégis egyértelmúen másfélék. Ők is szisztematikus, a család gondolkodásmódját és szokásrendjét meghatározó vallásosságban nőttek föl, s intézményi (iskolai, egyházi) vallásos nevelésben is részesültek. Az ideológiai dimenzióban stabil az alapvető elköteleződésük, a gazdag és sokoldalú családi és intézményes vallásos neveltetés révén sokrétű, és műveleti szinten is mobilizálható ismeretük, tudásuk halmozódott fel. Az idősebb generációtól örökölt vallásosságot egyértelműen megőrzik, azonban erősen reflektálnak az áthagyományozott kultúra szinte minden egyes elemére. A vallási ismereteket erőteljesen racionalizálják, így többnyire funk- 
cionálisan újraértelmezik a vallásosságot: „Hát egy jó ideig az embernek nem is jut eszébe kételkedni ebben. Nyilvánvalóan, amit a tanító néni vagy bácsi mond, az természetesen igaz. Igen. És igazából onnantól, hogy az ember eljut abba a korba, amikor megkérdôjelezi ezeket, talán akkor kevésbé volt fontos egy ilyen apró - olyan értelemben apróság, hogy igazából nem tudjuk, hogy inkább a szimbolikus jelentösége a fontos a hit ennek az oldalának. Úgyhogy azért kisebb is lett a jelentösége annak, hogy tényleg feltámadt-e, vagy mi történt kétezer évvel ezelőtt" (fiú). A szó szerinti értelmezések felől a szimbolikus értelmezések irányába való elmozdulást a hit intellektuálisan magasabb szintjének tekintik. A reflektív vallásosság kialakulásának feltétele ebben a típusban olyan környezet volt, amelyben kérdések, kételyek, kritika megfogalmazása is teret kaphatott, és ezek az átpártolás periódusában megvitatható alternatívákként kerültek tárgyalásra. Egyik esetben ez az egyházi iskola vallásoktatása keretében szerzett tapasztalatokhoz kötődik, s a viták megerősítő szerepéről árulkodik az alábbi interjúrészlet. „A legnyíltabb diskurzus egyértelmúen a gimnázium vége felé történt, ahol egy olyan atya került az osztályunkhoz, aki egyrészt felnôttként kezelt minket, és itt már igazából ő tett fel kérdéseket. Ez inkább megbeszélés volt, mint kérdések az elöadótól. És viszonylag nyíltan nyilvánítottunk véleményt" (fiú). Ebben a típusban a posztadoleszcens kor végére egyfajta intellektuális keresés alakul ki, melyben alapvetően megjelenik a vallásos szemlélet mint érték: „A tudat, hogy van valami, egy nyugodt, objektív rátekintés a jövőre, ami gyökerezhet abban, hogy tudjuk, hogy van valaki, aki gondoskodik vagy odafigyel az emberre. Szerintem ez egy olyan gondolat, ami mindenképpen érték lehet" (fiú).

Ugyanakkor az ideológiai, dogmatikai, valamint a rituális dimenziókban a korai vallási szocializáció során elsajátított elemek határozott kritikája, a felülvizsgálat igénye jelenik meg: „Vannak olyan kulcsfontosságú pontok, ahol nem tudok a számomra meghatározó, leginkább természetesen a katolikus egyház álláspontja mögé helyezkedni. Alapvetően például nem tartom fontosnak a formalitását a vallásosságnak, a díszes miseruháktól indulva az áldozásig elmenve akár. Nem tartom teljes mértékben helyénvalónak azt az álláspontot, hogy az ember alapvetően esendö vagy bünnel születik. Úgy gondolom, hogy ezt talán kicsit át lehetne gondolni, felül lehetne vizsgálni valamilyen szinten" (fiú). A rituális kérdésekben nem egyszerūen a kényelmesebbé tétel, a munka társadalmában domináns életvitelhez való igazítás igénye jelenik meg, mint az előző típusban, hanem a rítusok poliszemantikus jellegének felismerése $s$ a jelentések közötti újrarangsorolás a korai szocializáció során elsajátítottakhoz képest: „Ez [ti. az áldozás] egy - sokkal inkább, mint egy szentség magunkhoz vétele - egy részvétel egy közös tevékenységben. És inkább ezt tartom a pozitív oldalának" (fiú). Ebben a típusban a vallásosság konzekvenciáival kapcsolatos elvárások újszerú és reflektált megfogalmazásban, de hagyományos mintázatokra emlékeztetnek: „Semmiképp nem tesz önkritikusabbá és nem is magabiztosabbá abban a tradicionális értelemben, hogy magasabb az önértékelésem ettől. Inkább azt mondom, hogy optimistábbá tesz" (fiú). Véleményünk szerint nem hagyható figyelmen kívül, hogy e típus jellegzetessége, hogy a vizsgált interjúalanyok mindnyájan fiatal férfiak voltak. 


\section{A valláskárosult típus}

A valláskárosult típushoz tartozók az előző két típushoz hasonlóan egyértelműen vallásos nevelést kaptak, vagyis a családi szocializáció az előzőkhöz nagyon hasonló, talán még erősebb a szülői generációnak a lokális vallási kapcsolathálózatokba való beágyazottsága és intenzívebb a közösségi aktivitása. A szülők a közösségek aktív magjához tartoznak, jellemző, hogy a család a fiatalok gyermekkorában a szabadidejét a közösségben töltötte: „Hétköznap is van nagyobb ünnep, akkor arra is eljárnak. Folyamatosan ott vannak az egyházi életben” (fiú). „A gyülekezeti kirándulásokon mindig részt vettünk, családi napokon meg ilyeneken" (lány). Az e típushoz tartozó fiatalok kora gyermekkoruktól jelen voltak az intenzív közösségi életben, de a család intim miliőjében kevéssé manifesztálódott a vallásosság, nincs nyoma az értelmezésnek, a reflexióknak, a kérdéseknek. Az egyik interjúalany arról számolt be, hogy középiskolásként egy egyházi iskola közegében uralkodó ritualizálódott, inadekvát vallásgyakorlat erősítette a távolodását. „Előre jelzem, hogy nem akartam vallásos iskolába járni, de a sors mégis így hozta. Alapvetően reformátusok vagyunk, én pedig négy évig katolikus iskolába jártam. Mivel a kettőnél mások a szokások, én nem voltam hajlandó betartani a katolikus hagyományokat" (lány). A vallási transzmissziót a gyermekkor és a felnőttkor határán álló fiatalok sikertelenként értékelik: „Igen, mintha 180 fokos fordulatot vettem volna. Totál a vallás ellen fordultam, mivel rám volt kényszerítve" (lány). A vallásosság rituális dimenziójában mutatkozik meg a leglátványosabb kudarc: „Elsôsorban az katalizálta - az inditotta el, hogy a hanyagság, hogy nem érdekel, nem akarok elmenni, nem ezt akarom csinálni, most én inkább máshol leszek... unalmas volt. Nem akartam ott lenni egyáltalán. Fölösleges idötöltésnek tartottam” (fiú). „Néha szenvedés, néha élmény (...) Én a gyerekemre nem eröltetném rá a vallást, nem hurcolnám minden vasárnap templomba. Ha ö szívesen és örömmel jön, akkor elviszem. Viszont ha kinlódás neki a dolog, akkor nem erôltetném rá, mert egy életre elmenne tőle a kedve" (lány).

Az adoleszcens korszakban jelentkező vallásosság itt kiéleződő lázadás, a szülőkkel való komplex szembehelyezkedés egyik megjelenési formája. Egyrészt az ideális, megkérdőjelezhetetlen, úgynevezett tökéletes szülői vallásossággal való szakítás, ami elsősorban a rituális dimenzióban alakul éles szembenállássá. „És most van az, hogyőkjárnak templomba, én meg nem. Ök imádkoznak, én nem. De ez nem szül ellentétet köztünk. És egyébként a viszonyunk sem romlott ezáltal. De egyébként én nem vagyok ellene se a kereszténységnek. Tehát nem vagyok ellene a kereszténységnek mint hitvallásnak. Nem azért nem vagyok vallásos, mert ellene lennék, hanem csak más szemmel nézem a világot, és ennyi" (fiú). Az e típusba tartozók próbálnak kilépni a családi vallási szocializáció során elsajátított keretek közül, egyéni utat keresnek -_részben vallásos vagyok” (lány) -, s ez a keresés válik állandóvá: „Igen, hiszek. Egy istenben. De nem tudom, hogy ez-vagy hát nem tudom, hogy ez pontosan az-e az az Isten. Én abban hiszek, hogy van egy még nagyobb szellem, ami teret és idôt egyaránt - inkább azt mondanám, hogyha ezt Istennek nevezem, akkor ugyanazt mondom körülbelül, amit a kereszténység mond, hogy Isten 
itt van ebben a tér-idö kontinuumnak minden egyes részecskéjében, mert ő maga az, és te is vagy az, mert ö tartalmaz téged is, és ez oda-vissza. Én ebben hiszek, csak nem feltétlen fogadom el magát a történeteket, amiket az Újszövetség leír" (fiú). Az ideológiai innováció a hit tartalmának újrastrukturálásában nem bizonyul teljesen konzekvensnek. Az ehhez a típushoz tartozó egyének nem tudnak új struktúrákat felépíteni: „Nem tudom igazából pontosan, hogy én mit gondoltam. Szerintem akkor még nem gondoltam semmit, csak úgy éreztem, hogy unatkozom és nem akarok itt lenni. És utána egyébként, amikor így már jobban objektíven szemléltem a dolgokat, távolabbról, akkor rájöttem, hogy jól döntöttem, mert ezt meg kellett tapasztalnom, hogy eltávolodom ettől, és kicsit azért távolabbról is ránézzek az egészre" (fiú).

A vallásosság konzekvenciái között, melyek az eltávolodás ellenére egyértelműen pozitívan fogalmazódnak meg, néhol általánosabb, néhol bizonytalanabb értékeket nevesítenek az e típusba tartozók. Úgy véljük, ezeknek a közhelyessége a reflektálatlanságot, egy nem megküzdött kritikus szakasz nyomát őrzi: „Hát a vallásból ez a folyamatosan a békére való törekvés az, ami nekem nagyon tetszik, hogy még most is fontosnak tartok, és én közhelyeket mondok, de ez az egyenlöség meg az igazságosság, ez az, amit a mai napig is fö szempontoknak tartok egy közösségben" (fiú). A bizonytalanság hangja szólal meg egy másik interjúalany válaszában: „De például akár olyanba, hogy jobb ember lehet, aki vallásos, vagy az is lehet jó, aki nem” (lány).

\section{Közeledö típus}

Gyökeresen eltérő indíttatással rendelkeznek a közeledő típushoz tartozók, akiknek az életéből gyermekkorukban hiányzott a vallásos neveltetés, s épp az önállósulás, a felnőtté válás során kerültek közelebb az addig ismeretlen vallásossághoz. A nevetetésükre nemcsak a vallástalanság, hanem a vallási ismeretek hiánya is jellemző: „Én tizenkét éves koromban hallottam először azt, hogy Jézus. Hogy ki ô. Így, ennyire nem” (fiú). A vallásos kortársak által dominált kapcsolathálóban váratlanul megtapasztalt, megragadó élmények szerepe ebben a típusban a leglátványosabb. Az élményt világnézeti fordulat, bekapcsolódás, kötődés, beágyazódás, tanulás, ismeretszerzés, majd nemegyszer vezető szerep és szervezeti innováció követi, az adoleszcens vagy posztadoleszcens korszakban vallás nélküli gyermekkor után vallásossá vált egyének teljes identitásváltozáson mennek keresztül. A megtérésélményhez minden esetben közösségi élményen keresztül vezet az út: „Ez úgy folytatódott, hogy elhívott az ottani közösségbe. Ott volt egy hittantanár, aki csinált minden pénteken hittant, és elhívott oda. És az alapvetően jó volt. Késöbb volt, 16-17 voltam, amikor oda elvitt elöször. És az tök jó volt. Pénteken odamentünk, és akkor imádkoztak, imádkoztunk, a Bibliát olvastuk, akkor azt átbeszéltük" (fiú). Az elbeszélés során a személyrag változása utal a folyamat dinamikájára („imádkoztak, imádkoztunk”). Az iskolai vagy egyházi keretek között folyó hittanoktatás először nem az ismeretszerzés révén, hanem egy új kapcsolathálóhoz való csatlakozás erejével hat a fiatalokra. „Azért jártam hittanra elsősorban, mert meghirdették, és nagyon jó közösség alakult ki. Mindig jól éreztem magam, 
feltöltődtem, boldogan tértem haza" (lány). A közösség összetartó ereje stabil értékké válik, tehát a rituális dimenzió itt nem kritikát kap, hanem éppen a jelentésgazdag élmények terepe lesz. A teljes vallási ismerethiány és műveletlenség állapotából egy jelentős fordulattal vallási élménykeresés és tanulás mellett kötelezik el magukat: „Egy idő után más kapcsolatom lett Istennel, sokkal többet foglalkoztam a vallással, mint azelött... többet olvastam az igét, többet imádkoztam, komolyabban vettem a vallást" (lány). Vallásgyakorlatuk a közösségbe való bekapcsolódás alkalmával teljesedik ki, számos fejlődési stádiumon át haladva az egyén maga is aktív szervezővé válik: „És kitaláltuk, hogy csináljunk már valami közösséget, valamit indítsunk el, és csináltunk egy ilyen csoportot, és minden héten hétfönként összejártunk, hat órakor találkoztunk, és akkor hattól nyolcig imádkoztunk, beszélgettünk, valamikor elöadót is hivtunk vagy valamilyen atyát" (fiú). A vallási változás lépcsőfokain nemcsak új barátok, hanem egy-egy hittanoktató vagy pap/lelkész útmutatásait keresik, s professzionális lelkigondozókkal és közösségszervezőkkel találkoznak. A közeledő típusra az jellemző, hogy minden dimenzióban dinamikus változás következik be, a konverzió a kapcsolathálóra, az élettervekre, sőt még a munkavállalásra is kihat, s a fordulattal járó konfliktusoktól sem mentes.

\section{A nosztalgikus, reflektálatlan típus}

A nosztalgikus, reflektálatlan típushoz tartozó egyének vallási szocializációját érintőleges hatások, felszínes vonzódás és sporadikus érdeklődés jellemzi leginkább. Gyermekkorukból rendelkeznek ugyan némi vallásossághoz kapcsolódó ismerettel, melyet általában a nagyszülői generációktól tanultak a családban, de ezek szórványos, rendszerezetlen ismeretek. Jellemzően bizonytalanok vallási életútjuk tényadataiban is (pl. nem tudják, hogy meg vannak-e keresztelve). A rendszerváltás után kezdték iskoláikat, így a hittanoktatásban rövid, jobbára pozitív tapasztalatot szereztek, de a szerzett ismeretek nem szisztematikusak, még koherens múveltséganyagként sem mozgósíthatók. Egyfajta lappangó hiányérzet, fel-felbukkanó vallási szükséglet jellemzi a vallásossághoz való viszonyukat, de ez reflektálatlan marad, amit hűen tükröz az egyik interjúalany interjúernek, vagy talán önmagának feltett kérdése: „Kell legyen gondviselés, nem?” (lány). A vallásosság iránti igény bizonytalan ideológiai orientációban mutatkozik meg: „Ami történik, az mindenkinek az életében okkal történik, nem? Ez valahonnan csak meg van írva. Hogy milyen utat kell végigjárnunk, meg miért jövünk le, miért születünk” (lány). A vallásosságuk rituális dimenziója kialakulatlan, nincs saját felekezeti identitásuk, sem az egyházakhoz, sem pedig a közösségekhez nem kötődnek. Itt volt a leginkább kitapintható a konkrét kapcsolatháló erős hatása, hiszen attól függ a vallásgyakorlatuk, hogy éppen milyen összetételű a kapcsolathálójuk. A kapcsolatháló mellett a kritikus élethelyzetek lehetnek befolyással a vallásgyakorlatra, ebben a korcsoportban például a gyermekvállalással kapcsolatos sikertelen próbálkozások ilyenek. „Igen, mert az elején nem sikerült, mert próbálkoztunk. Nem hosszú ideig, de így nem, és akkor nem, és nem, és akkor utána már 
volt olyan, hogy imádkoztam, hogy segits meg" (lány). Vallási élményeik is az imameghallgatáshoz kötődnek. A vallásosság konzekvenciáival kapcsolatos elvárásaikat elsősorban a magatartási normák regulációjában tudják összefoglalni. „A nevelés, hát igazándiból az ismert nevelési rendszer valamilyen szinten egyenértékú, mert hogyha az ember elmegy, akkor nevelést is kap" (lány).

\section{Az érdektelen típus}

Az érdektelen típushoz tartozók inkább közömbösek nemcsak a vallásosság, hanem a lét alapkérdéseinek végiggondolása iránt is. Amikor az interjú során felmerültek ezek, egyfajta gyermekes, játékos felszínességgel, hedonizmussal tárgyalták őket. Már a szüleik sem részesültek vallásos neveltetésben, a családi szubkultúrában ezek a kérdések fel sem merülnek, és ettől eltérő vallási szocializációs hatás sem érintette meg őket, ebben a tekintetben stabilitás jellemzi őket. Az alapvető világnézeti kérdésekben nem túl szofisztikált, inkább naivnak mondható alternatív magyarázatmodellekkel operálnak: „Én mindig a szerencsében hittem, hogy most szerencsés vagyok éppen, vagy sem" (fiú).

A nosztalgikus, reflektálatlan típushoz tartozóktól az érdektelenség különbözteti meg őket: „Nem igazán tartom fontosnak, valahogy nem foglalkoztat a dolog, és kész. Mindig minden lesz valahogy, az, hogy hogy', az majd kiderül” (fiú). Az érdektelen típushoz tartozók nem rendelkeznek szisztematikus vallási ismeretekkel. A spirituális igény kielégül egyfajta konzumspiritualizmusban, mint például a médiumok vagy a horoszkópok. Arra a kérdésre, hogy hisznek-e valamilyen transzcendens rendezőelvben vagy jelenségben, sorra nemleges választ adnak, ennek ellenére a részletes válaszokból az derül ki, hogy alkalmanként, elsősorban a populáris média ösztönzésére, kisebb erőfeszítést tesznek ezek értelmezésére. „Nem feltétlenül, de egyébként írt már igaz dolgokat, de beletrafált. Ez egyébként furcsa nekem, hogy lehet valaki olyan, hogy mindig bejön neki, hogy azt irják, de egyébként lehet azért, mert a horoszkópnak megvan, hogy melyik hónaptól melyikig van, és valaki mikor született, mennyire van a horoszkóp közepében, mert én a sajátomnak a közepében vagyok, és énrám jellemzö, ami a Nyilasra jellemző, viszont van olyan ismerösöm, akire meg egyáltalán nem” (lány). A válaszadók és szüleik körében is előfordult kabalatárgyak használata (például szerencsehozó ruhadarabok az állásinterjúkon), tehát ezeknek a családi kultúrában valamiféle helyük van, de lényegesebb inter- vagy intragenerációs változás, elmozdulás, egyéni konstrukció nyomait nem tudtuk azonosítani ebben a típusban.

\section{Tudatos vallástalan típus}

A tudatosan vallástalan típushoz tartozók is az inter- és intragenerációs stabilitás határozott jeleit mutatják. A tudatosan vallástalan válaszadók vallásossággal kapcsolatos elutasító álláspontja a saját értelmezésük szerinti döntés eredménye, bár ezekben a családokban egyáltalán nem jelenik meg a vallásosság semmilyen formája, tehát ez gyermekkorban nem merült fel reális világnézeti alternatívaként. A 
korai és későbbi gyermekkori szocializációjuk során a szülők részéről is tudatosan, sőt büszkén, öntudatosan felvállalt vallástalanságról beszélhetünk. A világnézetük alapkövei a racionalizmus és az empirizmus, mely szerint a tapasztalati tényekkel nem alátámasztható állítások hamisak. „Én mindig is ilyen materialista neveltetést kaptam, hogy a világot magyarázzuk meg természettudományosan, és tulajdonképpen olyan dolgokban, amikre nincsenek tudományos eredmények vagy adatok, azokat kérdöjelezzük meg, és hogy végül is szükségtelen - lehet, hogy ezt már én raktam hozzá, de hogy számomra szükségtelen - valamiben hinni" (fiú). A vallásokkal kapcsolatos ismeretek itt családi beszélgetéseken, olvasmányokon alapulnak, és sokkal kiterjedtebbek, mint az előző két típusban. A vallásossággal kapcsolatos tapasztalatok a kortárs közösségekből, baráti körből származnak, ahol találkoznak valamilyen formában vallásosnak tartott fiatalokkal, azonban a tudatosan vallástalan típushoz tartozókat a konkrét kapcsolatháló hatása nem zökkenti ki tudatosan felvállalt álláspontjukról. A vallásosság elvetése itt reflektált, másokkal és önmagukkal megvitatott intellektuális produktum, ennek eredményeképpen a válaszadók a vallásosság társadalmi szintű, normaadó, integráló funkcióját mint konzekvenciát nagyra értékelik, de az egyéni szinten hasznosítható pszichológiai hatásokat a maguk számára nem tartják szükségesnek. Leginkább a vallásosság rituális dimenziójában mutatkozó aktivitásokat, az egyházi szervezetek működését és képviselőit bírálják és utasítják el. „De abban például, az mindig egy közös pont, hogy a tízparancsolat, abban egyetértünk, csak az nem közös pont, hogy ezt milyen közösségtöl kell eredeztetni, mert fóleg fontos-e ez, hogy milyen közösségtôl eredeztetjük, és ez az egész intézményesitett rész ez szükséges-e. Innentől már egyáltalán nem" (fiú). A tudatosan vállalt vallástalanság esetében a vallásossággal kapcsolatos elutasító álláspont családi transzmissziója eredményes, itt újraalkotásról kevésbé lehet beszélni, viszont a vallásosságtól való elzárkózás konzekvens és reflektált. A típushoz tartozók intellektuális kíváncsisága valamilyen szintű vallási ismeretekhez segíti őket, és a vallásosság konzekvenciális dimenzióban találnak a társadalom számára hasznosítható elemeket, de a világnézet, az élmények és a rítusok tekintetében elhatárolódnak a vallásosságtól.

\section{Összegzés}

Jelen kutatás célja elsősorban az volt, hogy megvizsgáljuk, a 21. század második évtizedében élő fiatal felnőttek esetében milyen mértékben érvényesülnek a vallási szocializációval kapcsolatos alapvető elméletek állításai. Az interjúk elemzésével arra vállalkoztunk, hogy megvizsgáljuk, milyen mértékben jellemzi a változás és a stabilitás a válaszadók vallási szocializációs történeteit, valamint a tudatosság és a reflektivitás mennyire jelenik meg a történtek felidézése és jelen álláspontjuk megfogalmazása során. A kutatás adatbázisának alapját 48 mélyinterjú szövegkorpusza adta, jelen tanulmányban a legfiatalabb korosztályból származó 18 interjút elemeztük, hogy megfigyeljük, a reprodukciós vagy a konstruktivista vallási szocializációs 
elméletek erősíthetők-e meg inkább ezen a mintán. Mivel a változás és a stabilitás egyszerre jelent meg a szövegekben, a vallásosság különböző dimenzióiba sorolható jelenségeket elkülönítve vizsgáltuk. Eredményeink azt bizonyítják, hogy kitapintható a vallási szocializáció reprodukciós modelljének érvényesülése, bár érdekes módon a legsikeresebb a transzmisszió a vallástalanság esetében, ahol az átörökített mintát korrekció nélkül tudják működtetni a fiatalok. A vallásosság eredményes vagy részben eredményes transzmissziója esetében sokkal gyakrabban találkoztunk az újrakonstruálás és az egyéni igényekhez, szükségletekhez igazítás jelenségével, ami a vallási szocializáció konstruktivista modelljének múködését erősíti meg. Ebben az esetben a történetmondás és a saját álláspont kifejtése során jelentős szerepet kap a tudatosság és a reflektáltság. Az összetett folyamatokat elemezve a vallási szocializáció dinamikája, iránya, a dimenziókhoz köthető mutatók alapján hét típust különítettünk el. A komfortosítva megőrző, az autonóm vallásosságot építő, a valláskárosult, a közeledő és a nosztalgikus reflektálatlan típusok a vallási szocializáció eredményeit tekintve az inkább vallásos mezőbe sorolhatók. A lét alapkérdései iránt érdektelenre és tudatosan vallástalanra a vallástalanság jellemző. A vallási szocializáció reprodukciós modellje lényegében a tudatosan vallástalanra és az érdektelenre érvényes, a többi típushoz tartozók a tapasztalatok és a kapcsolathálók intenzívebb vagy gyengébb nyomása alatt kétségtelenül újrakonstruálják az örökölt vallásosságot vagy vallástalanságot.

A 18 interjú természetesen nem tartalmaz elég információt ahhoz, hogy egy generáció vallásában bekövetkező változások irányát letapogassuk, ezért egyrészt az elemzésünk során kidolgozott szempontrendszert pontosabban mérő további interjúkra, majd ezt követően kvantitatív vizsgálatokra van szükség. Lényeges megállapításnak tekintjük, hogy a vallási szocializáció új interpretációjával jobban tudtuk értelmezni a folyamatokat, mint a korábban alkalmazottal. Az aktív, alkotó, az életút során többször újrastrukturálódó vallásosság megjelenése önmagában is jelentős vallási változásnak számít.

A vallásosság dimenzióinak elkülönített vizsgálata az elemzés során hasznosnak bizonyult, hiszen a különböző dimenziókban eltérő intenzitás és dinamika érvényesül, még akkor is, ha a rituális dimenzió bizonyult a leginkább mérhetőnek és az élménydimenzió a legnehezebben megragadhatónak. Az élmény- és tapasztalati dimenzió, mely a vallási érzéseket, megtérésélményeket foglalja magába, nehezen volt azonosítható néhány típusban, leginkább azért, mert beleszülettek, belenövekedtek a vallási életbe, pl. a komfortosítva megőrző vagy autonóm vallásosságot építő típus, néhányan pedig azért, mert az egyének életük során nem is keresték vagy pedig inkább közvetve élték át a jelenséget, pl. a tudatosan vallástalan vagy a lét alapkérdései iránt érdektelen típusok.

Összességében elmondható, hogy - noha a hatalmas szöveges adatbázis első elemzése nyomán megalkotott típusainkat joggal érheti az a kritika, hogy részben kiforratlanok - a típusok további finomítása, s az itt pontosított elemzési, csoporto- 
sítási szempontok segítségével sikerülhet gazdagítani azt a képet, amit az elsősorban statikus, keresztmetszeti állókép megalkotásának céljából született kategóriák nyújthatnak.

\begin{abstract}
Religious socialization has become a pressing issue in the context of religious socialization researches. It will also raise the question of whether the religious transmission can be interpreted through reproduction or constructivist approach. Previously, the reconstruction models influenced the approach of studying religious socialization. According to these models, socialization meant the adoption of the patterns of religious practice in the family. In this sense, socialization is periodical. The constructivist and the social network models of sociology significantly changed our conception of religious socialization. The earlier model was replaced by a model which lays on the activity, correlation and open-endedness. In this paper 18 qualitative interviews were analyzed. Since the religiosity is a multidimensional phenomenon, we analyzed the socialization process in six dimensions and we used Glock and Stark's model as base. Based on our results six types has been emerged and these findings has strengthen the constructivist approach.
\end{abstract}

Keywords: religious socialization; religious transmission; dimensions of religiosity, constructivist model of socialization

\title{
Irodalom
}

Bögre Zs. (2017): „Átmeneti” kategóriák erősödése az ifjúság vallásos önjellemzésekor. Metszetek, 6(3): 31-46.

Desrosiers, A. - Kelley, B. S. - Miller, L. (2011): Parent and peer relationships and relational spirituality in adolescents and young adults. Psychology of Religion and Spirituality, 3(1): 39-54.

Földvári M. - Rosta G. (1998): A modern vallásosság megközelítésének lehetőségei. Szociológiai Szemle, 22(1): 127-237.

Fowler, J. W. - Loder, J. E. (1982): Converstion on fowler's stages of faith and loder's the transforming moment. Religious Education, 77(2): 133-148.

Gereben F. (1997): Vallomások a vallásról. In Máté-Tóth A. - Jahn M. (szerk.): Studia religiosa. Szeged: Bába és Társa, 32-45.

Gereben F. (2003): Vallásosság és egyházkép - interjúk tükrében. Budapest: Kerkai Jenő Egyházszociológiai Intézet.

Glock, C. Y. (1962): On the study of religious commitment. Religious Education, 57(4): 98-110; doi:10.1080/003440862057S407.

Hámori Á. - Rosta G. (2013): Vallás és ifjúság. In Bauer B. - Szabó A. (szerk.): Arctalan (?) nemzedék. Budapest: NCSSZI, 249-263.

Hayes, B. C. - Pittelkow, Y. (1993): Religious belief, transmission and the Family: An Australian study. Journal of Marriage and the Family, 55(3): 755-766.

Hoge, R. - Petrillo, G. H. (1979): Youth and the church. Religious Education, 47(3): 305-313. 
Hunt, S. J. (2015): Believing vaguely: Religious Socialization and christian beliefs in Britain. Italian Journal of Sociology of Education, 7(3): 10-46.

Kovács Sz. (2014): A serdülők megtérési folyamatának intra- és interperszonális szempontjai és az értelemadás dilemmája. Studia Universitatis Babes-Bolyai, 59(1-2): 119-159.

Lee, B. H. - Pearce, L. D. - Schorpp, K. M. (2001): Religious pathways from adolescence to adulthood. Journal for the Scientific Study of Religion, 56(2). DOI: 10.1111/jssr.12367.

Martí, G. (2015): Religious reflexivity: The effect of continual novelty and diversity on individual religiosity. Sociology of Religion, 76(1): 1-13.

Martin, T. F. - White, J. M. - Perlman, D. (2003): Religious socialization: A test of the channeling hypothesis of parental influence on adolescent faith maturity. Journal of Adolescent Research, 18(2): 169-187.

Lagrange, H. (2014): The Religious Revival Among Immigrants and Their Descendants in France. Revue française de sociologie, 2(2): 359-367

Maliepaard, M. - Gijsberts, M. - Lubbers, M. (2012): Reaching the limits of secularization? Turkishand Moroccan-Dutch Muslims in the Netherlands 19982006. Journal for the Scientific Study of Religion, 51(2): 359-367.

Myers, S. M. (1996): An Interactive model of religiosity inheritance: The importance of family context. American Sociological Review, 61(5): 858-866.

Ozorak, W. E. (1989): Social and cognitive influences on the development of religious beliefs and commitment in adolescence. Journal for the Scientific Study of Religion, 28(4): 448-463.

Petts, R. (2009): Trajectories of religious participation from adolescence to young adulthood. Journal for the Scientific Study of Religion, 48(3): 552-571.

Pusztai G. (1997): Vallási szocializáció. In Falus I. - Báthory Z. (szerk.): Pedagógiai Lexikon. Budapest: Keraban Kiadó, 615-617.

Pusztai G. - Verdes E. (2002): A társadalmi tőke hatása a felekezeti gimnazisták továbbtanulási terveire. Szociológiai Szemle, 12(1): 89-106.

Pusztai G. (2004): Iskola és közösség. Budapest: Gondolat.

Pusztai G. (2011): A láthatatlan kéztől a baráti kezekig: Hallgatói értelmező közösségek a felsőoktatásban. Budapest: Új Mandátum Kiadó.

Pusztai G (2012): Hallgatói vallásosság és felsőoktatási beágyazottság. In Földvári M. - Nagy G. D. (szerk.): Vallás a keresztény társadalom után: Tanulmányok Tomka Miklós emlékére. Szeged: Belvedere Meridionale, 229-253.

Pusztai G. (2014): A felekezeti oktatás új szerepekben. Educatio, 1, 55-60.

Pusztai G. (2016): A szülők vallásossága mint a hatékony gyermeknevelés tőkeforrása. In Földvári M. (szerk.): Riport a családokról. Budapest: L’Harmattan, 427-447. Pusztai G. (2019): Vallási szocializáció és hatásai. Magyar Tudomány, 180(6): 834843. DOI: 10.1556/2065.180.2019.6.6. 
Sherkat, D. (2003): Religious socialization: Sources of influence and influences of agency. In Dillon, M. (ed.): Handbook of the sociology of religion. Cambridge: Cambridge University Press, 151-163.

Martin, T. F. - White, J. M. - Perlman, D. (2003): Religious socialization: A test of the channeling hypothesis of parental influence on adolescent faith maturity. Journal of Adolescent Research, 18(2): 169-187.

Tomka M. (1998). A vallásosság mérése. In Máté-Tóth A. - Jahn M. (szerk): Studia religiosa. Szeged: Bába és Társa, 18-31. 